\title{
ADVANTAGES AND APPLICATION OF PUNCTURED EPPENDORF TUBE TECHNIQUE (PETT) ON THE BIOLOGY OF THE BIRD CHERRY-OAT APHID, Rhopalosiphum padi (LINNAEUS) \\ Monira M. El-Fatih. \\ Piercing-Sucking Insects Research Department, Plant Protection Research Institute,Agriculture Research Center, Dokki, Giza
}

\begin{abstract}
This study demonstrates the advantages and important role of using Punctured Eppendorf Tube Technique (PETT) in different laboratory experiments such as behavioral, biological, bioassay of different small organisms such as Aphids. This technique simulated the natural growth stage of seeds under controlled conditions. PETT require low maintenance, simple, relatively inexpensive and allows monitoring of different small organisms. It depends on using Punctured Eppendorf Tubes as a closed media for seedling roots. The seeds to be germinated in a Petridish containing wetted Cotton or autoclaved soil or nutrient solution or Mulch according to the purpose of the experiment. After germination, the new seedlings to be transferred to Punctured Eppendorf Tubes. The punctured holes should be small to allow only the shoot to come out and not to allow any other organisms to move into the tube contents. The tubes to be filled with the prober media which may vary depending on the purpose of the study (i.e. Sterilized soil and water, nutrient solution...etc) and closed tightly. The units to be placed in ventilated plastic Petridishes covered with a piece of organza cloth to easy supply with normal or physical light and air conditions. Also, the PETT could be put in a closed sterile glass Petridishes for the purpose of pathogenic organisms' studies.

Results are closed to reality by using this technique. It allows facilitating similar environment around the host plant and the studied organism as much as natural situation. It reduces the hassle of using detached leaves or leaf discs and the problem of their deterioration over very short time or reduces the need to change them daily. The longer availability of an acceptable food source reduces handling time and disruption of organisms. This technique allows the monitoring of the natural interaction between the organism and its host plant due to the long time of organism existing on the host plant. This technique is prober for using with plant seedlings especially those belonging to Fam.: Gramineae as wheat, barley, rice, cereal weeds...etc. Using this technique make it easy to monitor the investigated organisms and its behavior on its host plant. This technique was used to study the biological aspects and life table parameters of the bird cherry-oat aphid, Rhopalosiphum padi (Linnaeus) at a constant temperature of $30^{\circ} \mathrm{C}$ as an example. The obtained results revealed that the life cycle, generation time, longevity and the life span durations were $6.58 \pm 1.50,7.96 \pm 2.73,13.15 \pm 4.60$ and $19.23 \pm 4.28$ days, while the recorded fecundity rate was 21.77 progeny/ female.

Calculated life table parameters showed that the net reproductive rate $\left(R_{0}\right)$, the mean generation time $(T)$, the intrinsic rate of increase $\left(r_{m}\right)$ and the Finite rate of increase $\left(\right.$ exp. $\left.r_{m}\right)$ values were 10.107, 10.56, 0.22 and 1.24, while the recorded population doubling time (PDT) in this study was 3.166 days.
\end{abstract}




\section{INTRODUCTION}

Most laboratory investigations on aphids involve growing the host plant either under glasshouses or constant environmental conditions (Adams and Van Emden, 1972). They mentioned that there are different caging techniques for aerial aphids. These techniques included whole plant cages (Type I and II); whole leaf cages (Type III); leave clip-on cages (Type IV); stem cages (Type V) and barriers to aphid movement (Types VI - VIII).

Adequate environmental conditions and food sources are essential for the successful of organisms rearing. To determine the intrinsic rate of increase of an insect or mite, food (s) must be provided which maximize development and reproduction (Abou-Setta and Childers, 1987). There are many previous studies on the methods of breeding as well as rearing for biological studies of mites (Gilstrap, 1977 and Abou-Setta and Childers, 1987) and on aphids (MacGillivary and Anderson, 1958 and Muller, 1966).

Leaf discs may have specific uses; however a good indication for nutritional mechanism of plant resistance may be that such resistance doesn't show in leaf discs (Van Emden et al., 1969). The use of detached leaves or leaf discs for aphid studies can't be recommended (Adams and Van Emden, 1972). The excision of plant tissue results in rapid and very considerable physiological changes in tissue which may actually reverse the suitability for aphids of the tissue as part of the whole plant (Muller, 1966).

Few studies have been conducted on various aspects of cereal aphid biology. Parameters obtained from life tables (Birch, 1948) clearly indicated organism's potential upper limits under ideal conditions (Mc Murtry et al., 1970 , Tanigoshi \& Mc Murtry, 1977). The Intrinsic rate of natural increase $\left(r_{m}\right)$ is a fundamental parameter for explaining the capabilities of a species for numerical increase. It gives the intrinsic capacity of an organism to increase in an unlimited environment (Birch, 1948)

The biology of the oat bird-cherry aphid, Rhopalosiphum padi (Linnaeus) on wheat plants at $22 \pm 2.5^{\circ} \mathrm{C}$ and $55 \pm 12 \% \mathrm{RH}$ was studied by ElFatih, 2000. She mentioned that the mean durations of the first, second, third, and fourth instars were $1.58 \pm 0.58,1.44 \pm 0.55,1.64 \pm 0.65$, and $1.8 \pm 0.587$ days, respectively. She added that the life cycle, life span, and viviparity durations were $7.375,11.94$ and $5.38 \mathrm{~d}$, respectively.

Abdel-Rahman et al. (2002), studied the development, survival and the reproductive potential of $R$. padi at constant temperatures of 20, 24 and $28^{\circ} \mathrm{C}$. They recorded that the time needed for the development of nymphal instars decreased significantly with the increase in temperature. Duration of nymphal stage ranged from 4.65 days to 8.31 days at 28 and $20^{\circ} \mathrm{C}$, respectively. They concluded that temperature of $24^{\circ} \mathrm{C}$ was the optimum temperature for the development and reproduction of the R. padi.

El-Heneidy et al. (2004) studied the biology of $R$. padi on barley plants. They concluded that the percentage of progeny reached maturity was $100 \%$. They concluded that the Respective mean generation time $(\mathrm{T})$ was 9.62 days. The $\left(R_{0}\right)$ and the $\left(r_{m}\right)$ values were 0.37 and 0.43 , respectively. Corresponding (exp. $r_{m}$ ) was 1.54, while the generation doubling time was 1.61 days. El-Sheikh et al. (2009) studied the biology and life table 
parameters of $R$. maidis on barley at different constant temperatures. They showed that the highest value (37.75) of the net reproductive rate $\left(R_{0}\right)$ was recorded at $20^{\circ} \mathrm{C}$ then decreased to 21.52 and 12.13 by the increase of temperature from 25 to $29{ }^{\circ} \mathrm{C}$. The lowest obtained value of $R_{0}(3.25)$ was recorded at $15^{\circ} \mathrm{C}$. The highest value of the intrinsic rate of increase $\left(\mathrm{r}_{\mathrm{m}}\right)$ for $R$. maidis was recorded at $25{ }^{\circ} \mathrm{C}(0.32)$ followed by $20{ }^{\circ} \mathrm{C}(0.28)$ and $29{ }^{\circ} \mathrm{C}$ (0.25), while the lowest one was recorded at $15{ }^{\circ} \mathrm{C}(0.06)$. The highest population doubling time (PDT) in this study (11.55days) was recorded for $R$. maidis at $15^{\circ} \mathrm{C}$. This value was lower $(2.77 \mathrm{~d})$ at $29^{\circ} \mathrm{C}$ followed by $(2.48 \mathrm{~d})$ and $(2.17 \mathrm{~d})$ at 20 and $25^{\circ} \mathrm{C}$, respectively.

This study aimed to demonstrate the advantages of using Punctured Eppendorf Tube Technique (PETT) in different laboratory experiments. This technique was used to study the biological aspects as well as life table parameters of the bird cherry-oat aphid, Rhopalosiphum padi (Linnaeus) at a constant temperature of $30^{\circ} \mathrm{C}$ as an example.

\section{MATERIALS AND METHODS}

Rhopalosiphum padi (Linnaeus) was collected from a wheat field and reared on wheat seedlings under the constant temperature of $30^{\circ} \mathrm{C}$. The number of aphid replicates used were 28 individuals. Wheat seedlings (Sakha 93 variety) were offered for feeding and maintaining aphids using Punctured Eppendorf Tube Technique (PETT). This technique permits to have a closed media for seedling roots and the media used for host plant germination. As shown in Plate 1 (Drawing sketch and Photos), this technique simulates the natural growth stage of seeds growth under controlled conditions. PETT require low maintenance, simple, relatively inexpensive, and allows monitoring of different organisms studies.

The seeds to be germinated in a Petri-dish containing wetted cotton or autoclaved soil or nutrient solution or mulch according to the purpose of the experiment and to be easy to separate the seedlings. After germination, the new seedlings is to be transferred to the Punctured Eppendorf Tubes. The punctured holes should be small to allow only the shoot to come out and not to allow any other organisms to move into the tube contents. The tubes to be filled with the prober media which may vary depending on the purpose of the study (i.e. Sterilized soil and water, nutrient solution...etc) and closed tightly. The units to be placed in ventilated plastic Petri-dishes covered with a piece of organza cloth to easy supply with normal or physical light and air conditions. Also, the PETT could be put in a closed sterile glass Petri-dishes for the purpose of pathogenic organisms' studies. 
Monira M. El-Fatih.

\section{DRAWING SKETCH}
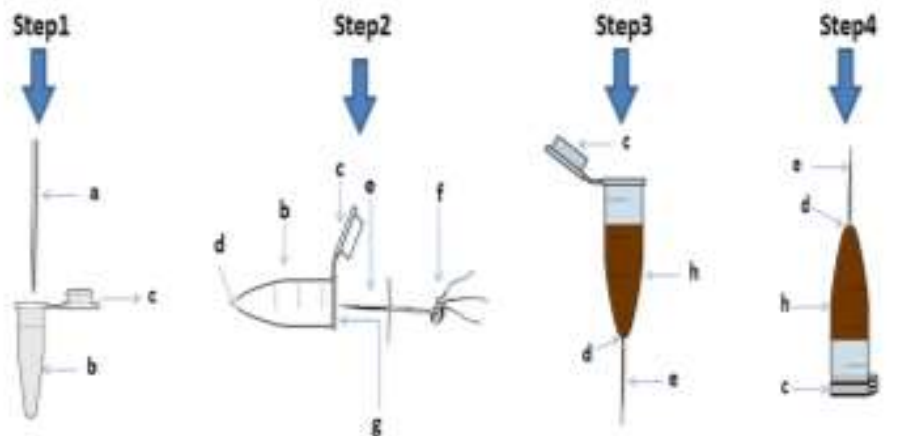

\section{PHOTOS}
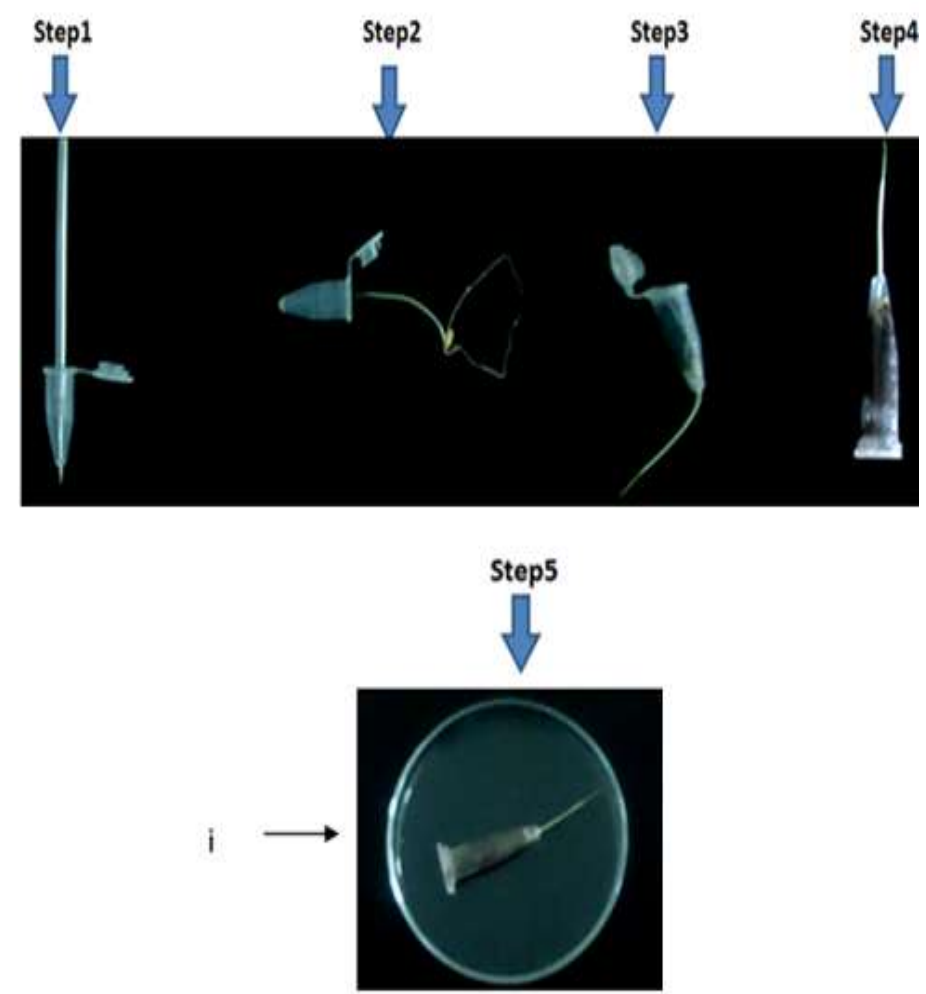

Plate (1): Structure and different steps of the Punctured Eppendorf Tube Technique (PETT)

$\begin{array}{ccc}a=\text { Punctured needle } & b=\text { Eppendorf tube } & c=\text { Cover cap. } \quad d=\text { Puncture (bore). } \\ e=\text { Seedling shoot. } & f=\text { Seedling root } \quad g=\text { Direction of seedling insertion. }\end{array}$ $\mathrm{H}=$ Media. $\quad \mathrm{i}=$ Seedling unit placed in a plastic Petri-dish for observation.

This technique was used to study the biological aspects and life table parameters of $R$. padi at a constant temperature of $30^{\circ} \mathrm{C}$ as an example. 
The newly-born progenies produced by field-collected mothers were gently transferred separately using a fine hair brush to wheat seedlings germinated in Punctured Eppendorf Tube inside clean Petri-dishes containing filter paper discs. A single aphid can be transferred from a source to a new plant by wetting a fine-hair brush with water and picking the aphid up gently with the wet top of the brush when transferred, the aphid usual wonders a little but then settles down readily on its new substrate (Adams and Van Emden, 1972)..

These groups of nymphs were monitored daily until death and the following observations were recorded:

- Developmental durations of each nymphal instar.

- Durations of adult female stage and life span.

- Fraction of progeny reached maturity.

- Survival of individuals throughout their developmental duration.

The obtained data of the life table studies were analyzed according to Birch (1948) using Life 48 Basic Computer Program (Abou-Setta et al., 1986). Sex ratio was considered

\section{RESULTS AND DISCUSSION}

This study demonstrates the advantages and important role of using Punctured Eppendorf Tube Technique (PETT) in different laboratory experiments such as behavioral, biological, bioassay of different small organisms such as Aphids. This technique simulated the natural growth stage of seedlings under controlled conditions. PETT require low maintenance, simple, relatively inexpensive and allows monitoring of different small organisms. It depends on using Punctured Eppendorf Tubes as a closed media for seedling roots. The seeds to be germinated in a Petri-dish containing wetted Cotton or autoclaved soil or nutrient solution or mulch according to the purpose of the experiment. After germination, the new seedlings to be transferred to Punctured Eppendorf Tubes. The punctured holes should be small to allow only the shoot to come out and not to allow any other organisms to move into the tube contents. The tubes to be filled with the prober media which may vary depending on the purpose of the study (i.e. Sterilized soil and water, nutrient solution...etc) and closed tightly. The units to be placed in ventilated plastic Petri-dishes covered with a piece of organza cloth to easy supply with normal or physical light and air conditions. Also, the PETT could be put in a closed sterile glass Petri-dishes for the purpose of pathogenic organisms' studies.

Results are closed to reality by using this technique. PETT allows facilitating similar environment around the host plant and the studied organism as much as natural situation. It reduces the hassle of using detached leaves or leaf discs and the problem of their deterioration over very short time or reduces the need to change them daily. The longer availability of an acceptable food source reduces handling time and disruption of organisms. This technique allows the monitoring of the natural interaction between the organism and its host plant due to the long time of organism 
existing on the host plant. This technique is prober for using with plant seedlings especially those belonging to Fam.: Gramineae as wheat, barley, rice, cereal weeds...etc. Using this technique make it easy to monitor the investigated organisms and its behavior on its host plant.

This technique was used to study the biological aspects and life table parameters of the bird cherry-oat aphid, Rhopalosiphum padi (Linnaeus) at a constant temperature of $30^{\circ} \mathrm{C}$ as an example.

Data presented in Table (1), revealed that the first, second, third and the fourth nymphal instar durations of $R$. padi lasted for $2.04 \pm 0.78,1.38 \pm$ $0.51,1.54 \pm 0.88$ and $1.62 \pm 0.65$ days. The pre-parturation, viviparity duration and post-parturation periods lasted for $1.38 \pm 1.80,9.46 \pm 4.67$ and $2.38 \pm 1.80$ days. The recorded durations of the life cycle, generation time, longevity and the life span durations were $6.58 \pm 1.50,7.96 \pm 2.73,13.15 \pm$ 4.60 and $19.23 \pm 4.28$ days, respectively. The estimated fecundity rate was 21.77 progeny/female.

As presented in Table (1), the calculated life table parameters for $R$. padi showed that the net reproductive rate $\left(R_{0}\right)$, the mean generation time $(T)$, the intrinsic rate of increase $\left(r_{m}\right)$ and the finite rate of increase (exp.rm) values obtained from this study were $10.107,10.56,0.22$ and 1.24 , while the recorded population doubling time (PDT) in this study was 3.166 days.

Most laboratory investigations on aphids involved growing the host plant either under glasshouses or constant environmental conditions were reported by (Adams and Van Emden, 1972). They mentioned that there are different caging techniques for aerial aphids. These techniques are: whole plant cages (Type I and II); whole leaf cages Type III; leave clip-on cages (Type IV); stem cages type V and barriers to aphid movement (Types VI - VIII). They summarized observations about some of these techniques as follows:

Whole plant cages (Type I), light intensity is drastically reduced Whole plant cages (Type II), ventilation of such cages is a serious problem. The host plant is often badly affected by increased shading, temperature and relative humidity. Also, the muslin covers strikingly reduce the leaf area of enclosed plants, accelerate senescence of leaves and retard the expansion of young leaves. Such cages are not recommended. An improvement may be conducted by isolating the cage from the moist soil surface used a simply cast plaster of Paris base to retain both plant and cage as well as to absorb surplus moisture.

Leave clip-on cages (Type III), such cages are often in the form of a ventilated box or cylinder_surrounding the leaf with a seal around the petiole of cotton wool or a tied cloth skirt. Problems of some plastic materials toxicity should be applied again. The cages usually need external support. 
Table (1): Biology and life table parameters of R. padi at $30^{\circ} \mathrm{C}$

\begin{tabular}{|l|c|}
\hline Parameters & Obtained Value \\
\hline First nymphal instar (days ) & $2.04 \pm 0.78$ \\
\hline Second nymphal instar (days ) & $1.38 \pm 0.51$ \\
\hline Third nymphal instar ( days ) & $1.54 \pm 0.88$ \\
\hline Fourth nymphal instar ( days ) & $1.62 \pm 0.65$ \\
\hline Life cycle ( days ) & $6.58 \pm 1.50$ \\
\hline Generation time (days ) & $7.96 \pm 2.73$ \\
\hline Pre- Parturation & $1.38 \pm 1.80$ \\
\hline Viviparity duration ( days ) & $9.46 \pm 4.67$ \\
\hline Post-Parturations & $2.38 \pm 1.80$ \\
\hline Longevity & $13.15 \pm 4.60$ \\
\hline Life span ( days ) & $19.23 \pm 4.28$ \\
\hline Fecundity rate (progeny/female) & 21.77 \\
\hline Net reproductive rate $\left(\mathrm{R}_{\circ}\right)$ & 10.107 \\
\hline Mean generation time $(\mathrm{T})($ days $)$ & 10.56 \\
\hline Intrinsic rate of increase $\left(\mathrm{r}_{\mathrm{m}}\right)$ & 0.22 \\
\hline Finite rate of increase $\left(\right.$ exp. $\left.r_{\mathrm{m}}\right)$ & 1.24 \\
\hline Generation doubling time $(\text { days })^{\star}$ & 3.166 \\
\hline
\end{tabular}

$\left({ }^{*}\right)=\ln 2 / \mathrm{rm}$

The study results are in accordance with the findings of Richter and Balde, 1993. They mentioned that heat stress at $30^{\circ} \mathrm{C}$ reduced reproduction and fecundity in $R$. padi on barley plants. The results are also similar with those obtained by Abdel-Rahman et al. (2002). They reported that the development of nymphal instars of $R$. padi decreased significantly with the increase in temperature. Duration of nymphal stage ranged from 4.65 to 8.31 $d$ at 28 and $20^{\circ} \mathrm{C}$, respectively. $R_{0}$ values, indicated that the pest increased $20.64,35.09$ and 11.94 times within a single generation at 20,24 and $28^{\circ} \mathrm{C}$, respectively. The population doubling time (DT) decreased with the increase in temperature up to $24^{\circ} \mathrm{C}$. The intrinsic $\left(r_{\mathrm{m}}\right)$ and finite $(\lambda)$ rate of increase, which express the relationship between fecundity, generation time and survival, increased by increasing temperature. Values of $r_{m}$ at 24 or at $28^{\circ} \mathrm{C}$ (0.266 and 0.2294$)$ were approximately 1.5 times higher than those of the pest at $20^{\circ} \mathrm{C}(0.1744)$. They concluded that temperature of $24^{\circ} \mathrm{C}$ is the optimum temperature for the development and reproduction of $R$. padi.

Also, El-Heneidy et al. (2004) reported that the mean durations of the first, second, third, fourth instars and life span averaged $1 \pm 0,1.17 \pm 0.38,1 \pm 0$, $1.36 \pm 0.49$ and 23.82 days, respectively. Percentage of progeny of $R$. padi on barley, reached maturity was $100 \%$. Respective mean generation time $(T)$ was 9.62 days. The $\left(R_{0}\right)$ and the $\left(r_{m}\right)$ values were 0.37 and 0.43 , respectively. Correspondent (exp $r_{m}$ ) was 1.54, while the generation doubling time was 1.61 days. 


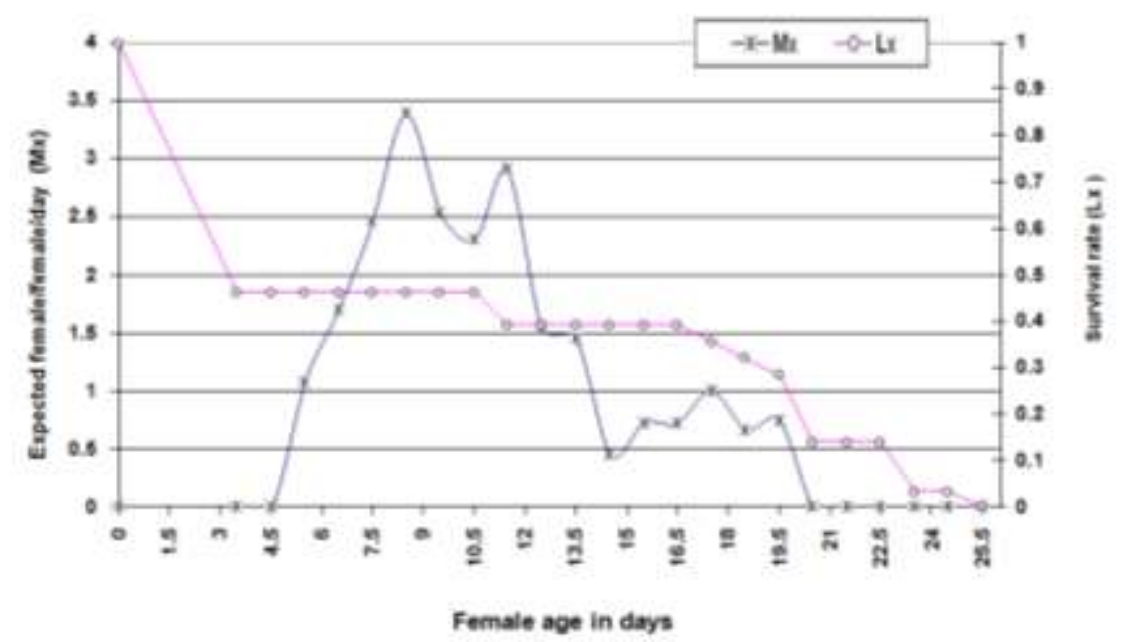

Fig. (1): Natality and survivorship of R. padi at $30^{\circ} \mathrm{C}$

\section{REFERENCES}

Abdel-Rahman, M. A. A.; A. M. Ali and A. G. Ali (2002). Reproductive potential of the oat bird-cherry aphid, Rhopalosiphum padi L. (Homoptera: Aphididae) at constant temperature. $2^{\text {nd }}$ International Conference, Plant Protection Research Insitiute, Cairo, Egypt, 21-24 December.

Abou-Setta, M. M and C. C. Childers (1987). A modified leaf arena technique for rearing phytoseiid or tetranychid mites for biological studies Fla. Entomol., 70 (2): 245-248.

Abou-Setta, M. M; R. W. Sorrel and C. C. Childers (1986). Life 48: A basic computer program to calculate life table parameters for an insect or mite species. Fla. Entomol., 69(4): 690-697.

Adams, J. B. and H. F. Van Emden (1972). The biological properties of aphids and their host plant relationships. Aphid technology with special references to the study of aphids in the field (Chapter2). Edited by Van Emden, H. F. Academic press. London and New Yourk. pp48:104.

Birch, L. C. (1948). The intrinsic rate of increase of insect population. J. Anim. Ecol., 17:15-26.

El-Fatih , M. M. (2000). Cereal aphids in Egypt and their impact on wheat. M. Sc. Thesis, Fac. Agric., Cairo Univ., Egypt. 146pp.

El-Heneidy, A. H.; H. M. Sobhy; S. M. N. Abd-El-Wahed and W. Z. A. Mikhail (2004). Biological aspects and life table analysis of cereal aphid species and their parasitoid, Aphidius colemani Viereck (Hymenoptera: Aphidiidae). Egyptian Journal of Biological Pest Control, 14 (1), 43-51. 
El-Sheikh, M. A. K.; Elnagar, S.; El-Hariry, M. A. and El-Fatih, M. M. (2009). Life table-parameters and heat units for the corn leaf aphid, Rhopalosiphum maidis (Fitch), reared on barley host plant. The $4^{\text {th }}$ conference on recent technologies in agriculture Challenges of Agriculture Modernization. pp: 101-109.

Gilstrap, F. E. (1977). Table-top production of tetranychid mites (Acarina) and their phytoseiid natural enemies. J. Kansas Entomol. Soc. 50: 229-33.

MacGillivary, M. E. and Anderson, G. B. (1958). Development of four species of aphids (Homoptera) on potato. Can. Ent. 90, 148-155.

Mc Murtry, J. A.; Huffaker, C. B. and Van de Vrie, M. (1970). Ecology of tetranychid mites and their natural enemies: A review .1. Impact of spray practices. Hilgardia 40: 331-390.

Muller, H. J. (1966). Uber die Ursachen der unterschiedlichen Resistenz von Vicia fabae L. gegenuber der Bohnenblattlaus. Aphis (Doralis) fabae Scop. IX, Der Einfluss okologischer Faktoren auf das Wachstum von Aphis fabae Scop. Entomologia exp. Appl., 9, 42-66.

Richter, S. and Balde, M. (1993). Influence of temperature on the development and reproduction of pea and oat aphids on field beans and spring barley. Mitteilungen der Deutschen Gesellschaft fur Allgemine und Angewandte Entomologie. 8 (4-6): 591-597.

Tanigoshi, L. K. and Mc Murtry, J. A. (1977). The dynamics of predation of Stethorus picipes (Coleoptera: Coccinellidae) and Typhlodromus floridanus on the prey Oligonychus punicae (Acarina: Phytoseiidae, Tetranychidae). Hilgardia 45: 237-288.

Van Emden, H. F. (1969). Plant resistance to Myzus persicae included by a plant regulator and measured by aphid relative growth rate, Entomologia exp. app., 12, 125-131. 
مميزات واستخدام تكنيك أنابيب الابندورف المثقوبـة في الاراسـة البيولوجيـة لمن

الثوفان

منيرة محمد الفاتح

معهز بحوث وقاية النباتاتــ مركز البحوث الزراعيةـ الاقي - جيزة

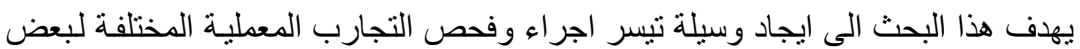

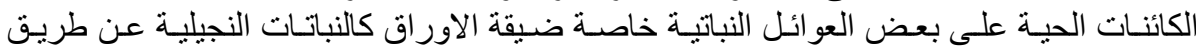

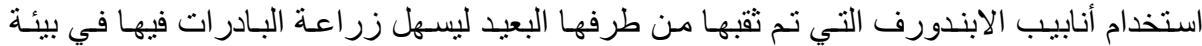

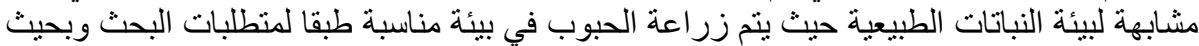

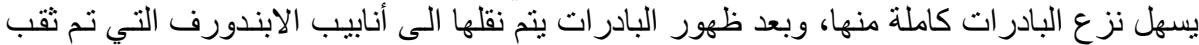

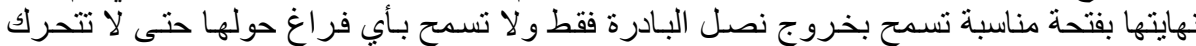

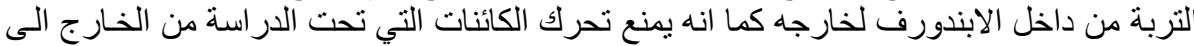

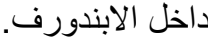

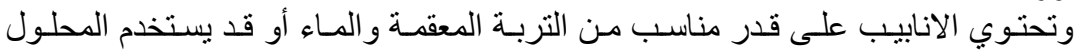

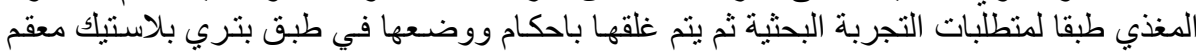

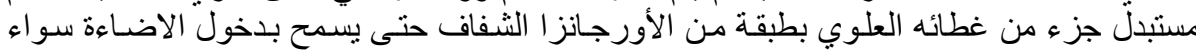

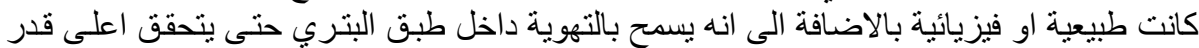

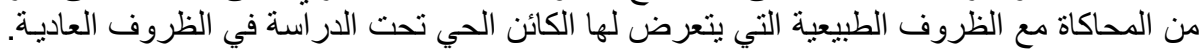

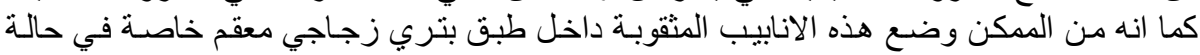

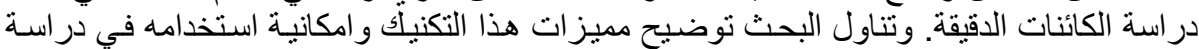

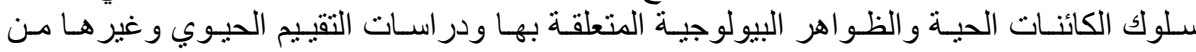

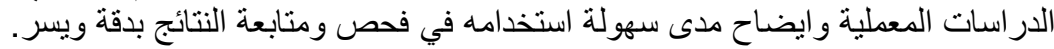

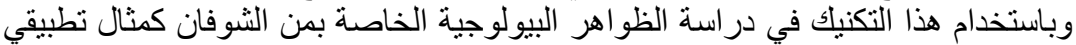

تحت ظروف المعمل على بادرات القمح (صنف سخا 93) على درجة حرارة ثابتة 30 بـ أظهرت

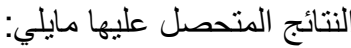

كانت فترة دورة الحياة Life cycle

(13.15 Generation time

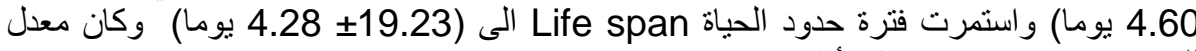

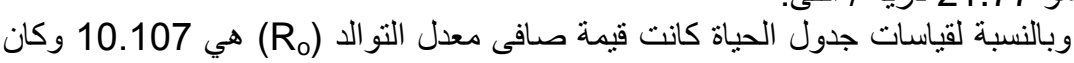
للخصوبة هو 21.77 ذرية / أنثى.

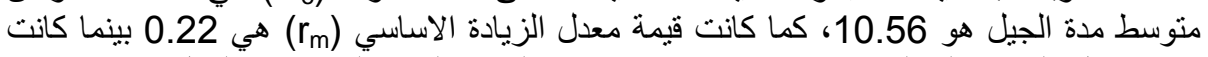
قيمة معدل الزيادة المطلق هو 1.24، في حين كان الوقت اللازم لتضاعف الجيل (PDT) هو التياني 3.166 يومًا. 
J. Plant Prot. and Path., Mansoura Univ., Vol. 5 (12), December, 2014

$\begin{array}{llllllllll}1151 & 1152 & 1153 & 1154 & 1155 & 1156 & 1157 & 1158 & 1159 & 1160\end{array}$

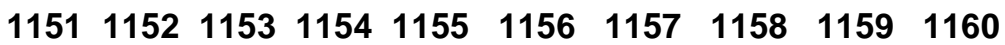

$\begin{array}{llllllllll}1151 & 1152 & 1153 & 1154 & 1155 & 1156 & 1157 & 1158 & 1159 & 1160\end{array}$ 